UDC $629.45: 621.335: 621.318 .14: 519.71$

\title{
軌道振動を考慮した吸引力形磁気浮上車両 の制御理論に関する研究
}

\author{
正員中川聡子（横浜国立大） \\ 正山員 村 (工学院大)
}

\section{1.はしがき}

筆者らは，これまで常電導マグネットを用いた财引 力形磁気浮上車の研究を行なってきた。磁気浮上車は レールとの接触かないため䮴音や振動の公害問題も少 なく、草諭がないため走行特の摩耗すなく保守が容易 であるという利点があることから，多方面での利用が 期待される。

常常導磁気学上システムに関する研究は，現在まで のところ一点支持系の解析加ら始まり，二点支持系解 析一台車 (四点支持系) 解析まで進んでいる。元来常電 導マグネットを用いた磁気浮上系は不安定であるため 適切な閉ループ制御が必要であるが，この支持系に最 適制御の理論を用いることによって十分に安定した浮 上特性が得られるととが験証されている(1)(2)。しかし 或際の磁気浮上系は二台車，一車体で構成されている ため，台車単独の制湖の考え方で不十分である。之 こで本諭文では，前後の台車の二つの極端な場合老想 定し，車画全体を見渡した制御法について説明を行な

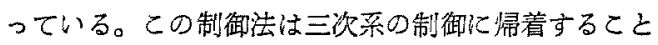
ができるため, 制御回路が簡筆なうえ, 浮上磁石はそ れぞれ独立に制御を行なえる利点がある。また，軌道 を車両が走行する場合，すなわち，可とうはりに順次 移動荷重が加わる場合の解析す，軌道振動上浮上磁石 の吸引力との相互作用の点で重要である。この場合， 磁気浮上系之軌道との相互作用を考慮儿入れた制监が 必要であり，本論文で示した制御法を用いれば，軌道 の防振を四るととが可能となることが示されている。 本論文では，まず二台車・一車体で構成される柤両 の制御法について述へ，次に軌道防振効果老目的とし

Reserch for Electromagnetically Levitated Vehicle Runnig on Rails Considering Rail Oscillation. By Toshico Nakagawa, Member (Yokohama National Univesity) \& Sakae Yamamura, Member (Kogakuin University).

中川隐子：正置，横国立大学工学部

山村 莡: 正直, 工学院大学工学部
た制衙法について述へ，それらについて走行シミュレ ーションの結果を例として示した。

\section{2. 磁気浮上台車の最適制御理論}

本論文において筆者らは，図1のような二台の磁気 浮上台車に二次サスペンションを介して車体をのせた 磁気浮上車両について解析を行なう。従来の鉄道では ボギー式台車が広く用いられているが，磁気浮上車侣 もとの台車方式を採用すると, 乘り心地, 曲線通過の 点で利点が有り，前後台車間の相互作用を少なくする 呠きを持たせることる可能である。

台車には，准行運動，上下㞄動，ローリング，ピッ チング、枕じれ，左右動，ヨーイングの六つの運動モ 一ドがある。これらのモードの制御には，支持系しし て台車の四隅の浮上用マグネットと，案内系として左 右四個のマグネットが用いられるが，支持系亡案内系 は台車の重心がその平面内の中心仙るるすれば，そ れぞれ独立に扱うことができる。本論文では，より複 雑な支持系のみを解析するむのとし，报うモードは上 下動 $(g)$ モード，ピッチング( $(\varphi)$ モード，ローリンダ $(\theta)$ モード，ねじれ $(\delta)$ モードとする。案内系伅ついて は支持系と全く同㥞比报えるため，本論文沈执いては 解析の対象としない。

さて，一台草の制御諭は確立されており，台草の各 運動モードは一点交持マグネットの制御理論之同様に 扱うととができる(1)(3)。しかも最適制湖理論を用いて

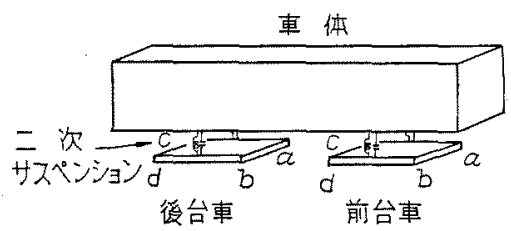

図 1 二台の台車に支持された車両モデル

Fig. 1: Model of vehicle body supported on two trucks. 


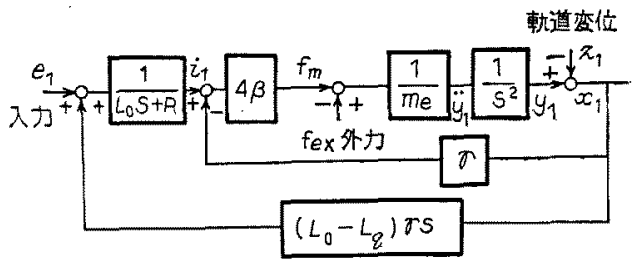

図 2 三次系開ループブロック网

Fig. 2. 3-d degree close loop , block diagram of models of motion of electromagnetically levitated vehicle.

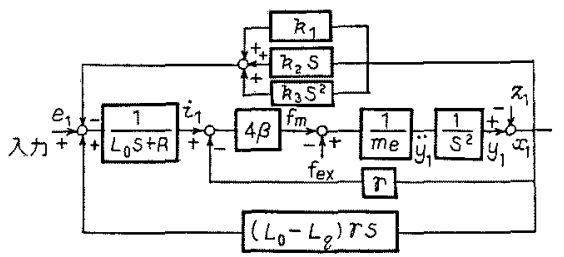

図 3 三次系閉ループブロック図

Fig. 3. 3-d degree close loop block diagram of models of motion of electromagnetically levitated vehicle.

各モードを制御し，相似制御の考え方を導入して各浮 上マグネットを独立に制御できることが示されてい る。その手法として，各運動モードの関ループブロッ ク図は图2に示すような三次系であるから，モードど との質量 $m_{\theta}, m_{\theta}, m_{\varphi}$ の平均質量 $m_{\varepsilon}$ 亿対して最適制 御理諭䘮用いて制御系を設計し，区3の上うな三つの 独立したフィードバックループを持った閉ループ制御 を行なうととである。

各 $g, \theta, \varphi, \delta$ モードの状態変数は変換マトリクス $\boldsymbol{T}$ によって，台車の四禺にある各 $a, b, c, d$ マグネット の状態裂数に変換するととができ，相似制御の考え方 によって各マグネット間の相互作用をたち切ることが できる。そのため，四閩のマグネットはそれぞれ独立 に制御するととができる。従って，制御信号として必 要な状態变数は， $g, \theta, \varphi, \delta$ 系の变数ではなく, 各マグ ネットごとの信号でよいため，制御回路は非常に簡素 なむのよなる。

運動モードでとの吸引力を $F_{\theta}, F_{\theta}, F_{\varphi}, F_{\delta}$ とし，台 車四隅のマグネットの吸引力を， $F_{a}, F_{b}, F_{c}, F_{d}$ とす ると，これらの力の間の関係姑 (1)式のように洯わさ れる。また，モードごとの電王，電流，加速度，速度，

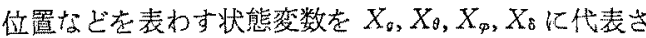
せマグネットの状恧变数を $X_{a}, X_{b}, X_{a}, X_{d}$ 亿代表さ せると，とれらの関係仕(2)式のように表わされる。 その際の変換マトリクス $\boldsymbol{T}$ は(3)式のようである。

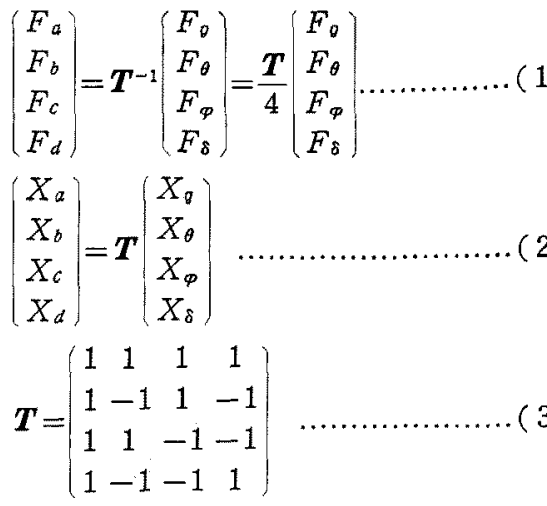

\section{3. 磁気浮上車両の制御}

既に図 1 に示したように，磁気浮上車は二台の浮上 用台車を持っている。前節では一台車の制御方式につ いて説明を行なったが，二台車と一車体で構成された 磁気浮上車両の制御系の次数は 8 次となり, 全体を最 適に制御しようとする場合，8つのフィードッバクが 必要となる。このような制御を行なう場合，台車のみ ならず，車体にす制御用信号を得るためのセンサーが 必要となることにもなり，しかも前後の台車の制御信 号の交换も必要となるため，制御回路ははん雑とな る。そのうえ，制御可能なシグナル数には奏用上限度 があり，後節で述べる軌道防振のために用いる制御用 信号としてあ残しておかなけ机ばならない。このよう な観点加ら，前後台車はそれぞれ独立に，しか子簢素 な制御を行なう必要が生じる。

さて，台車の制御特性を问上させると制御上のしゃ 断周波数が大きくなり，軌道振動や外力などの種々の 高以周诐数の外乱付刘しても追往できる。その結果， 乗り心地が悪くなり，前後二台の台車に車体を直付り することは望ましくない。台車，事体間には，1 Hz 程 度の非常に低いしゃ断周波数它持つ二次サスペンジョ ンを介するととにより，台車汃らの振動を車体へ伝え ないフィルタの作用を持たせることが必要である。こ の上うな二次サスペンジョンな介するととにより，前 後二台の台車と車体の相互作用岏次の上うな極端な二 つの場合に近似て考えることが可能であり，実際の 台車と車体の関係は，これら二つの㙞合の間に位琾す るものと考えてよい。

(i) 自由端の場合 図4のどとく台車の二次サ スペンジョンの上端部が開放されて目由端と考えた場 合に，二つの台車は相互の影響を受けずに進むため， この場合の制御は個々の台車の独立な制御で㢃く，2 節に説明した图3のブロック罒により制御系を設計す 
㣪台車

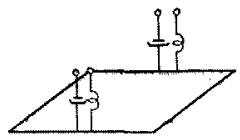

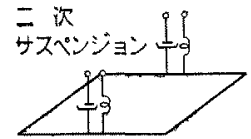

前台車
园 4 自由端の場合

Fig. 4. Case of free end.

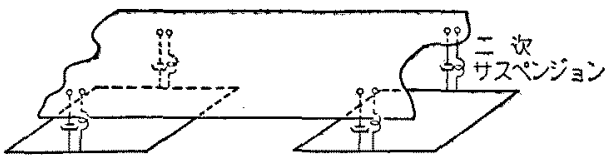

後台車

暗台車

园 5 固定端の場合

Fig. 5. Case of fixed end.

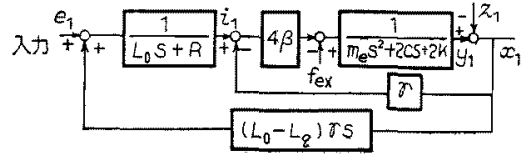

図 6 三次系開ループブロック図(固定端)

Fig. 6. 3-d degree open loop block diagram (fixed end).

るととが可能である。との場合車体の質量がゼ口の場 合と等価と考㝋て良いことから，てのような各台車独 立な三次系の制御定，磁気浮上車息の自由端制御また は質量ゼロの制鹳と呼ぶことにする。

（ii）国定端の場合 図 5 どとく前後台車の二次 サスペンジョンが固定壁に接続された場合にも，二台 の台車は相互の影響を受けずに進むため，これらの制 御は個々の台車の独立な制御で良い。しかし，この場 合にはマグネットの開ループブロック図は図6に示す あのとなり，てれによって制御系を設計するととが可 能である。乙の場合にあ秃峏三次であるから三つの信 号をフィードバックして制御を行なえぱよい。この場 合，車体の質量加然限大の場合と現象が等価となるこ と加ら，乙のような各台䡩独立な三次系の制御を磁気 学上車両の固定端制御または無限大質量の制御と呼るシ ことにする。

上記の 2 種類の手法で，図3，図6 のブロック図中 の最適なフィードバック定数 $k_{1}, k_{2}, k_{3}$ を最適制御理 論加ら求的る。そとで，自由端の系と固定端の系を状 態方程式で表わすと，(4)，(5)式のようである。

$$
\frac{d}{d t}\left(\begin{array}{c}
x \\
\dot{x} \\
\ddot{x}
\end{array}\right)=\left(\begin{array}{ccc}
0 & 1 & 0 \\
0 & 0 & 1 \\
\frac{4 R \gamma \beta}{m_{e} L_{0}} & \frac{4 L_{q} \gamma \beta}{m_{e} L_{0}} & \frac{-R}{L_{0}}
\end{array}\right)\left(\begin{array}{c}
x \\
\dot{x} \\
\ddot{x}
\end{array}\right)+\left(\begin{array}{c}
0 \\
0 \\
\frac{4 \beta}{m_{e} L_{0}}
\end{array}\right) u
$$

$$
\begin{aligned}
& \frac{d}{d t}\left(\begin{array}{c}
x \\
\dot{x} \\
\ddot{x}
\end{array}\right)=\left(\begin{array}{c}
0 \\
0 \\
\frac{4 R \gamma \beta-4 K R}{m_{e} L_{0}}
\end{array} *\right. \\
& \left.\begin{array}{c}
1 \\
* \frac{4 L_{q} \gamma \beta-4 C R-4 L_{0} K}{m_{e} L_{0}} \\
0 \\
* \frac{-\left(m_{e} R+4 C L_{0}\right)}{m_{e} L_{0}}
\end{array}\right)\left(\begin{array}{l}
x \\
\dot{x} \\
\ddot{x}
\end{array}\right)+\left(\begin{array}{c}
0 \\
0 \\
\frac{4 \beta}{m_{e} L_{0}}
\end{array}\right) u
\end{aligned}
$$

但し，状態変数 $x$ はマグネットと対问面とのギャップ 長の定常值からの変化分を表わしている。また, $u$ は 系への入力で

$$
u=-\left(k_{1} x+k_{2} \dot{x}+k_{3} \ddot{x}\right) \text {. }
$$

である。 $K, C$ は台車亡車体の間にある二次サスペン ジョンを表わすもので，Kはぱね定数，Cダンピング 定数であって，自由端の系の(4)式には含まれない。

このように，(4)，(5)式の系に対して，状態変数 $x, \dot{x}, \ddot{x}$ に対する重み $q 1^{2}, q^{2}{ }^{2}, q^{2}$ とした(7)式のよ うな評価関数 $C F$ を定めてフィードバック定数 $k_{1}, k_{2}$, $k_{3}$ を定めると次のようになる。

$$
C F=\int_{0}^{\infty}\left(q_{1}^{2} x^{2}+q_{2}^{2} \dot{x}^{2}+q_{3}^{2} \ddot{x}^{2}\right) d t
$$

(i) 目由端の場合

$$
k_{1}=1.8 \times 10^{5}, \quad k_{2}=4.62 \times 10^{3}, k_{3}=7.21 \times 10
$$

(ii) 固定端の嚗合

$$
k_{1}=1.08 \times 10^{5}, \quad k_{2}=4.60 \times 10^{3}, \quad k_{3}=6.05 \times 10
$$

但し，ここで用いた磁気浮上車両は表1に示すような 質量安むち，断面 $3 \mathrm{~m} \times 3 \mathrm{~m}$ で $20 \mathrm{~m}$ の車画長を有す るもので， $1 \mathrm{~m}^{2}$ 当り $19 \mathrm{t}$ の吸引力を持つ浮上用磁石 を用いるとして，諸元を想定したものである。この諸 元をもとに, 上記, 設計した采は，しゃ断周波数 $f_{0}=$ $8.3 \mathrm{~Hz}$, 減裹定数 $\zeta=0.61$ となるように，(7)式の $q_{1}{ }^{2}, q_{2}{ }^{2}, q_{3}{ }^{2}$ を定めている。

この結果から自由端と固定端の間で $k_{3}$ に $15 \%$ 程 度の差は生じるものの，他の $k_{1}, k_{2}$ にはほとんど差は ないととが判る。

さて，以上のような2種類のフィードバック制御を 二台の台車にはどこし，图 1 のような車雨走行させ た埸合在考える。

図1に示したように，二次サスペンジョンは台車の 左右端部の中央に一対設置されている。このような配 置を行㛢うと台事のピッチングモードは事体には伝わ らない。車両が走行する場合に必要のない台車の運動 
表 1 磁気浮上車両の諸元

Table 1. Dimensions of electromagnetically levitated vehicle.

\begin{tabular}{|c|c|c|}
\hline 部号 & & 值 \\
\hline$m_{g}$ & 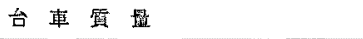 & $4,000 \mathrm{~kg}$ \\
\hline$m_{\theta}$ & 台車ローリング等価窴最 & $3,300 \mathrm{~kg}$ \\
\hline$m_{\bullet}$ & 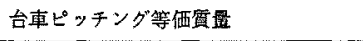 & $2,500 \mathrm{~kg}$ \\
\hline$m$ & 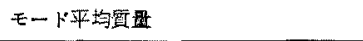 & $3,300 \mathrm{~kg}$ \\
\hline$x_{0}$ & 軌道とマグホット問のギャップ長 & $12.0 \mathrm{~mm}$ \\
\hline$i_{0}$ & マグネット劯磁酷流 & $20.0 \mathrm{~A}$ \\
\hline$R$ & マグネット些抗少 & $4.52 \Omega$ \\
\hline$r$ & $r=i_{0} / x_{n}$ & $1,666.7 \mathrm{~A} / \mathrm{m}$ \\
\hline$\beta$ & 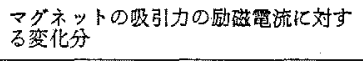 & $430.6 \mathrm{~N} / \mathrm{i}$ \\
\hline$L_{0}$ & マグネットインダクタンス & 2. $989 \mathrm{H}$ \\
\hline$L_{q}$ & マグネット渴れインダクタンス & $0.448 \mathrm{H}$ \\
\hline$l$ & 台莗 卧 & $5.0 \mathrm{~m}$ \\
\hline$L$ & 南両の長む & $20.0 \mathrm{~m}$ \\
\hline$K$ & 二次サスペンション活祬定数 & $156,800 \mathrm{~kg} / \mathrm{s}^{2}$ \\
\hline$C$ & 二次サスベンションダンピング定数 & $36,000 \mathrm{~kg} / \mathrm{s}^{2}$ \\
\hline$L_{z}$ & 軌道の 1 スパン長 & $20.0 \mathrm{~m}$ \\
\hline $6 x$ & 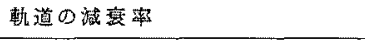 & $3 \%$ \\
\hline$f_{z}$ & 喠道の固有撮怔数 & $10.0 \mathrm{~Hz}$ \\
\hline$M_{z}$ & 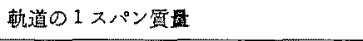 & $84,000 \mathrm{~kg}$ \\
\hline$M_{g}$ & 事 体 望 & $27,000 \mathrm{~kg}$ \\
\hline$M$ & 車体ローリング等価筫剆 & $13,000 \mathrm{~kg}$ \\
\hline$M_{\infty}$ & 本体ピッチング等覀筫需 & $9,100 \mathrm{~kg}$ \\
\hline
\end{tabular}

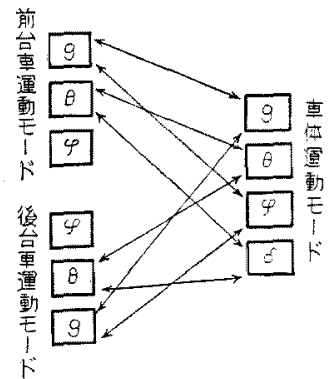

图 7 台車の運動モード と車体の運動モ一 ドの相互関係

Fig. 7. Interaction between mode of truck motion and mode of vehicle motion.

モードは，車体任わらない方が事り心地などの点で 有利である。とのように二次サスペンションを設置す ると，前後台車の各㖶動モードと草体の荤動モードと の相互関係は図7亿示すようなむのとなる。また，こ れらの関係は(8)〜(10)式で表わすととができる。こ こで, $K$ とCは二次サスペンションのばね定数上減衰 定数であり，W, $W_{\theta}, W_{\phi}, W_{\delta}$ は車体の各運動モード ごとの定常位置加らの变化分, $M_{p}, M_{\theta}, M_{p}, M_{8}$ は車
体の各運動モードの等価質量， $Y_{\theta F}, Y_{\theta F}$ は前台車の上 下動モードとローリングモードの定常位置加らの変化 分, $Y_{\theta R}, Y_{\theta R}$ は後台車の上下動モードとローリングモ 一ドの定常位置加らの変化分とする。また， $F_{\theta F}, F_{\theta F}$ は前台車の上下動モード，ローリングモードの吸引力 の定常值加らの変化分であり， $F_{q R}, F_{\theta R}$ は後台車の各 モードの吸引力の定常值からの变化分である。また， 車体の対じれ関しては，車体の枕れの減衰定数を $C_{\delta}$ ，ば䘺数を $K_{\delta}$ としている。

$$
\begin{aligned}
& m_{g} S^{2} Y_{g F}=2(K+C S) \\
& \times\left(W_{\theta}+W_{\phi}-Y_{Q F}\right)-F_{\theta F} \\
& m_{\theta} S^{2} Y_{\theta F}=2(K+C S) \\
& \times\left(W_{\theta}+W_{\delta}-Y_{\theta F}\right)-F_{\theta F} \\
& \text {............. } \\
& m_{q} S^{2} Y_{o R}=2(K+C S) \\
& \times\left(W_{\theta}+W_{\varphi}-Y_{\theta R}\right)-F_{g R} \\
& m_{\theta} S^{2} Y_{\theta R}=2(K+C S) \\
& \times\left(W_{\theta}+W_{\delta}-Y_{\theta R}\right)-F_{\theta R} \\
& \text {............................ }(9) \\
& M_{\theta} S^{2} W_{\theta}=-2(K+C S) \\
& \times\left(2 W_{\theta}-Y_{g F}-Y_{\theta R}\right) \\
& M_{\theta} S^{2} W_{\theta}=-2(K+C S) \\
& \times\left(2 W_{\theta}-Y_{\theta F}-Y_{\theta R}\right) \\
& M_{\varphi} S^{2} W_{\varphi}=-2(K+C S) \\
& \times\left(2 W_{Q}-Y_{Q F}-Y_{Q R}\right) \\
& \left(M_{\delta} S^{2}+C_{\delta} S+K_{\delta}\right) W_{\delta} \\
& =-2(K+C S)\left(2 W_{\delta}-Y_{\theta F}+Y_{\theta} R\right)
\end{aligned}
$$

図8(a)は $1 \mathrm{~mm}$ の軌道段差を車両が通過するとき

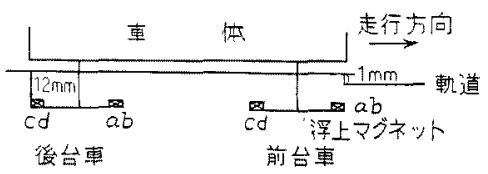

(a) 軌道段差之車車

(a) Model of vehicle and rail whith defference in level

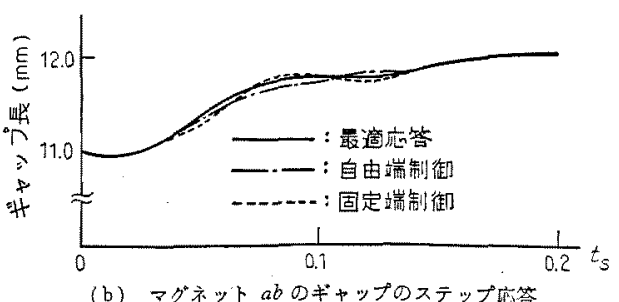

(b) Step response of gap of magnet $a b$.

图 8

Fig. 8. 


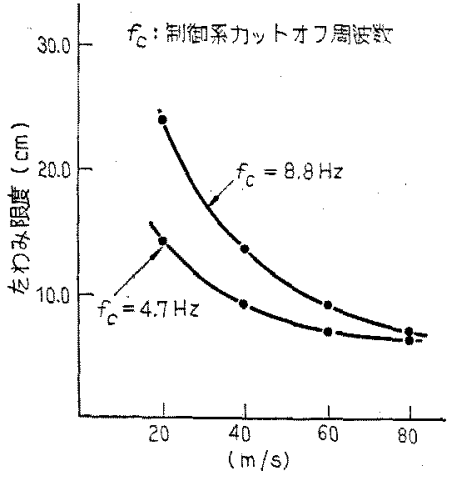

図 9 走行速度一たわみ限度特轶

Fig. 9. Curve of bending limit for velocity of electromagnetically levitated vehicle.

の㥞子を示した委ので，走行速度は $80 \mathrm{~m} / \mathrm{s}$ とする 図8（b)は，このときの前台車の前方 $a, b$ マグネット

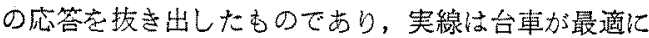
応答した場合のものであり，破線は自由端制御，点線 は固定端制御をそれぞれ台車，一台東の車雨にほどこ した場合の応答である。とれらすべて段差に突入して から0.2梨娞には完全汇定常ギャップ $12 \mathrm{~mm}$ 庄保っ て走行している。また三者の間には応答上の差はほ とんどなく，このことから車体の乘った䡛再全体の制 微に対してむ，個々の台車のみを考えた三次系の制御 で十分であることがわかる。これは，台車と車体間の 二次サスペンジョンのカットオフ周波数か： $1 \mathrm{~Hz}$ 程度

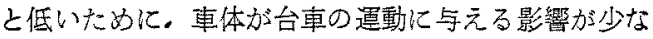
いからであるが，ての周波数は実用されている值の範 国である。

図9は、三次系の制触を行なった舅合，たわみのあ る軌道老走行させたときのギャップ長の応管の計算機 シミュレーション結果加ら求めたたすみ許容限度をグ ラフにしたものである。たわみ嫆限度とは，これ以 上㨁道をたわませるとマグネットが軌道に衙突すると いう限度のことである。実用域の走行速度（最高時速 $300 \mathrm{~km} / \mathrm{h}$ 程度)では，制御系のカットオフ周波数が 高いほよ゙，走行速度が幄いほどたわ許容限蒦が大き く安全である。一般の軌道のたわ加は $1 \mathrm{~cm}$ 程度であ ること加ら，たわみのみ考える場合には，この程度の 制御で十分亡考えられる。

\section{4. 軌道を含む五次系の最適制御}

前節までの解析で，車体す含めた磁気浮上台車の制 御は，前捘台草においてそれぞれ三つのフィードパッ クを各々の磁石に独立に行なうことで十分であるとと
が判ったが，この解析では軌道学弹性体として扱って いない。従って，磁気深上草が䒠際の軌道上を走厅す る場合に振勒を誘起するため，前節までの制御法では 不十分である。軌遵振動を防ぐためには軌道にコンク リート它埋め込むなどの策を構じなければならないが このような手段には多くの建設費がかかる。そこで軌 道棈造を簡単化し，浮上磁石の吸引力の制制によって 轨道防振機能をむたせることが必要上なる。軌道の防 振を図るには，軌道加らの信号吉制御詨象としなり机 ばならないが，序上体に取り付りられたギャップセン サや加速動センサの信号から等洒的に把握するととが 可能である。本節では多点支持の場合の轨道も含めた

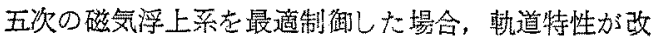
善されることを示す。

前節の議論加らも独立した個々の台車の制御法を用 い机ば草両全体の系の走行解析は十分であるから，こ こでは一台の台車に注目する。このとき，軌道の慣性 項を $\mathrm{M}_{z} / 2$ ，可上う性を表わすばね係数を $k_{z}$ ，制勤係 数を C とした場合，動作点のまわりで線形化された 式は（1）式のようである。軌道の等洒質軖が，はりの 全質量 $M_{x}$ の半分亡なるのは，はりの力学などで示 されることである。但し漂字の abcd は台車の四隅の マグネット表わす。文た各変数の位置関係は圈 10 のようである。但し $C_{x}$ は $2 * \zeta_{x} * \omega_{x}, k_{x}$ は $w_{x}^{2}$ で 尚召。

$$
\frac{M_{z}}{2} * \frac{d^{2} z_{m i}}{d t^{2}}=-k_{z}\left(z_{m i}-z_{n i}\right)
$$

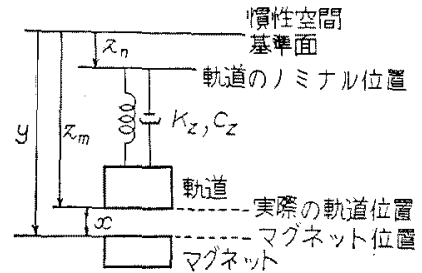

图 10 可とう性をもったレールを含む 基本モデル

Fig. 10. Basic model with flexible rail.

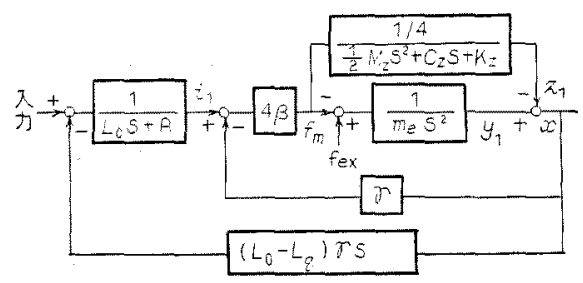

図 11 開ループ五次系ブロック線図

Fig. 11: 5-th degree open loop block diagram. 


$$
\begin{array}{r}
-C_{z}\left(\dot{z}_{m i}-\dot{z}_{n i}\right)+f_{m i} \\
\quad(i=a, b, c, d) \ldots .
\end{array}
$$

これらの式え用いて $a, b, c, d$ マダネット系加らg， $\theta, \varphi, \delta$ Eード齐への変換を変換行列 $T$ を用いて行な い，図2のブロック図に組み込めば図 11 のような軌 道む含めた五次系開ループブロック線図が描ける。こ の系を制御するための五つのフィードバック信号とし て $x_{1}, \dot{x}_{1}, z 1, \dot{z}_{1},-i$ を選び，最適制御理諭によって フィードバック係数 $k_{1}, k_{2}, k_{3}, k_{4}, k_{5}$ を設計する。設 計に際しては入力を 古。

$$
\begin{aligned}
& C F=\int_{0}^{\infty}\left(q_{1}^{2} x_{1}^{2}+q_{3^{2} z_{1}}^{2}+u^{2}\right) d t \ldots \ldots \\
& u=-\left(k_{1} x_{1}+k_{2} \dot{x}_{1}+k_{3} g_{1}+k_{4} \dot{z}_{1}-k_{5} i\right) \ldots
\end{aligned}
$$

ここで， $q_{3}^{2}$ は軌道防振のため付け加えられた重み 付け定数である。

種々の重子 $q_{3}^{2}$ について表1のような軌道に対し， 鼠適なフィードバック系を作った場合，系の極の位置

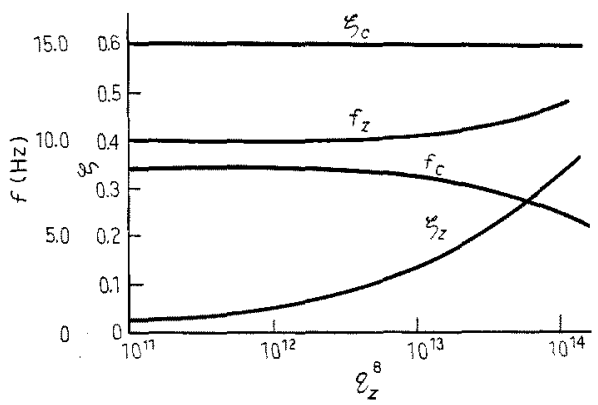

图 12 最適制御を行なった五次モデルの特性

Fig. 12, Characterics of 5-th degree model with optimum control.

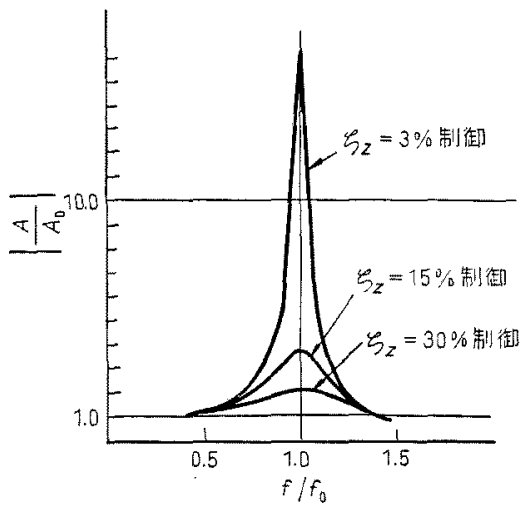

図 13 五次系フィードバック制御を行なう 場合の軌道の周波数特性

Fig. 13. Frequency characteristics of rail oscillation (5-th degree feed back control).
からその系の制御特性が判断できる。图 12 は, 重み $q^{2}{ }^{2}$ に対して系のカットオフ周波数 $f_{c}$, 減衰定数 $\zeta_{c}$, 軌道の固有振動数 $f_{z}$ ，ダンピング係数 ら を計算した もである。図 12 からむ判るように，浮上特性の良否 を左右するら。や $f_{0}$ が大きく劣化しない領域で，軌道 が本来むつ非常に低いダンピング定数を制御によって 1 けた程度增加させることす可能となる。

このように軘道を含めた五次系（四 11）に $k_{1} \sim k_{5}$ ま でのフィードバック制御を行なうと，レールへの外力 に対するたわみの周波数特性は図 13 のようになる。 横轎は軌道の固有振動数(ここでは $10 \mathrm{~Hz})$ で規格化し てあり，縦軸は静荷重を加えた場合のたわみで規格化 している。このように，制御を行なえば軌道の固有振 動数之同じ周波数の外乱を受けたときに起とる共振ピ 一クをなだからにするととが可能となる。但し，軌道 スパン $20 \mathrm{~m}$ て，固有振動数 $10 \mathrm{~Hz}$ の場合，杪速 200 $\mathrm{m}$ で走行する場合以外仙，走行による共振状態は起き ないから実用範囲での心配はないと言える。

\section{5. はりのカ学と走行シミュレーション}

磁気浮上車両が軌道上を走行する場合，浮上用マグ ネットの吸引力による荷重が軌道としてのはりにかか る。との荷重は速度 $V$ を持つ移動荷重であり，しか む，浮上マグネットが台車の前後部に分かれているた め，一車両にははりに対し四つの荷重の作用点が存在 する。はりの振動の一つの荷重点に対して線形と考え て良いため,はりの運動位各移動荷重点による運動の 和として求められる。

図 14 に軌道を示す。 $L$ はスパン長, $P_{0}$ は荷重， $M_{z}$ は軌道質量, $V$ は走行速度, $\zeta_{x}$ は軌道の減衰比, $w_{x}$ は軌道の固有角速度， $X$ は軌道端からの距離とすると 軌道振勤 $Z$ は(14)式のように表わすととができる。

$$
\begin{aligned}
& \ddot{Q}+2 \zeta_{z} \omega_{z} \dot{Q}+\omega_{z}{ }^{2} Q \\
& \quad=\left(2 P_{0} / M_{z}\right) * \sin (V \pi / L) \\
& \phi(X)=\sin (\pi X / L) \\
& Z=Q(t) \phi(X)
\end{aligned}
$$

（14)式の第1式を解けば，(15)式のようになる。

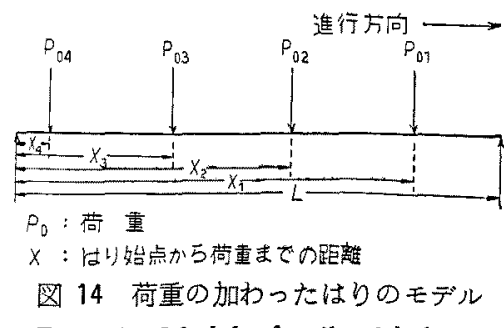

Fig. 14. Model of rail with load. 


$$
\begin{aligned}
Q(t)= & C_{1} \exp \left(-\zeta_{z} \omega_{z} t\right) * \sin b t \\
& +C_{2} \exp \left(-\zeta_{z} \omega_{z} t\right) \cos b t \\
& +E_{1} \sin (a t+\delta) \\
& Z=Q(t) \sin (\pi X / L)
\end{aligned}
$$

但L,

$$
\begin{aligned}
& E_{1}=2 P_{0} /\left(M_{z} * \sqrt{\left.\left(\omega_{z}^{2}-a^{2}\right)^{2}+4 \zeta_{z^{2}} \omega_{z^{2} a^{2}}\right)}\right. \\
& C_{1}=-E_{1}\left(\zeta_{z} \omega_{z} \sin \delta+\pi V / L * \cos \delta\right) / b \\
& C_{2}=-E_{1} \sin \delta, \quad a=\pi V / L, \\
& b=\sqrt{\omega_{z}{ }^{2}-\zeta_{z} \omega_{z}^{2}} \\
& \delta=\tan ^{-1}\left(2 \zeta_{z} \omega_{z} /\left(\omega_{z}{ }^{2}-a^{2}\right)\right)
\end{aligned}
$$

とする。はりに $N$ 個の移動荷重加加わる場合を考元 ると, $i$ 番目の荷重がはりに進入してからの時間を $t_{i}$ とすれば軌道端から $X$ の地点のはりの振動の(16) 式 のように合成される。

$$
Z=\sum_{i=1}^{N} Q\left(t_{i}\right) * \sin (\pi X / L)
$$

荷重 $P_{0}$ は1 荷重点当たりの車両質量之台車左右 2 個のマグネットの吸引力の変化分の和となり, 二台車 一車体の浮上システムに上記(15)，(16)式老組み合和 せることでシミュレーションを行なうことができる。 浮上システムの諸元は表1に示すむのとしてシミュレ ーションを行なえは，図15, 図 16 の如くなる。

図 15 は一車両は走行させる場合の走行速度 $V$ と

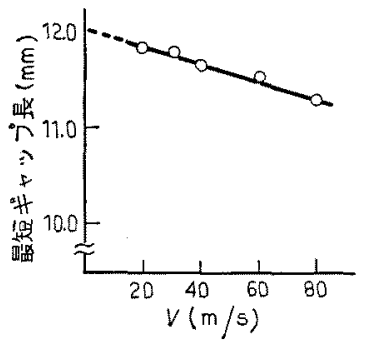

図 15 走行速度之最 短ギャップ長

Fig. 15. Curve of the shotest value of gap for vlocity.

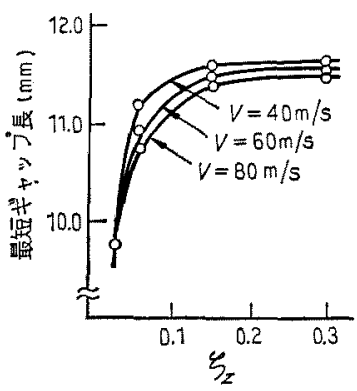

図 16

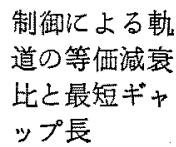

Fig. 16. Curve of the shortest value of gap for damping constant with optimum control.
最短ギャップ長を示すむのである。最短ギャップ長と は定常12 mmのギャップに対し走行中にマグネットが 靲道に最も引き寄せられたときのギャップ長のととで ある。制御系は五次系でカットオフ周波数 $8.1 \mathrm{~Hz}$, 減衰率 0.6 , 軌道の振動数 $10.0 \mathrm{~Hz}$ 制御比上って得 られる軌道の等価减衰率である。

図 15 は，第 4 節で述べた五次柔の制御を行なった 場合の最短ギャップ長と減哀定数の関係を示すむので ある。五次系の制御法は軌道の減衰率を增加させる働 きがあるだぬ，その制䅉上の等洒的な減衰率を横軸に 上っている。走行速度によって，大きな差巽はみられ ないととがわかる。

これらの結果加ら，使用しうる走行速度（最高時速 $300 \mathrm{~km} / \mathrm{h}$ 程度) の領域では，軌道とマグネットの衝突 は十分の余裕をむって起とらないことがわかる。ま た，五次系フィードバック制御の制御定数を適切に選 べば非常に安定した走行が可能となるととがわかる。

\section{6. むすび}

本論文は，磁気浮上車両と軌道を含好た系の制御柔 について述べ，その計算機シミュレーションを行なっ たものである。磁気浮上車両の制御は台車方式を採用 すると、一台車のみに注目した制御法で十分であるこ とが示された。また，車両走行に際しての軌道振動を 防ぐには五次系の制御を行なえばよく，車両が走行し ている間(制御が効いている間) 岻，軌道の減衰率は 制御によって大きくとれ，防振効果を持たせることが 可能であることがかかった。そうするととによって， $300 \mathrm{~km} / \mathrm{h}$ 以上の実用範国内の速度で走行しても軌道 の固有振動数などによる影響はないと考えられる。本 論文は磁気浮上車雨の浮上系の設計に対して，台車間 の相互作用を考濾た制御法，浮上磁石の独立制御法 建設賔の大部分を占的尚軌道の防振法等々の基本方針 を総括的に述ぺたすのと考える。

最後に，本研究を行なうに当たり横浜国立大学芹沢 康夫教授に貫重なご意見をいただき，心より感謝いた します。

(昭和 59 年 4 月 20 日受付)

\section{文 献}

（1）大西・山村・林:「吸引篦磁石北磁気浮上方式心最道制御 要学論 B 98, 387 (昭 53-4)

（2）中川・山村・大酉：「磁気浮上台龺の制御理論之実馱」昭 56 雷気学会全大 No. 794

（3）山村・大西・正田：「吸引力形常電㽝磁気、浮上台車の制御系 理論」雷学諭 B 99, 752 (昭 54-11)

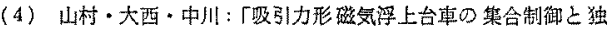
立制御了靁学耣 B 101，109(昭 56-2) 